\title{
Impact of Employee Engagement and Organizational Culture in High Performing Accredited University of Saudi Arabia
}

\author{
Afroze Nazneen \\ Asst. Professor, College of Business, University of Jeddah \\ Jeddah, Saudi Arabia \\ Mohammad S. Miralam \\ Assoc. Professor, College of Business, University of Jeddah \\ Jeddah, Saudi Arabia
}

\author{
Sayeeduzzafar Qazi (Correspondence author) \\ Professor, College of Business Administration \\ University of Business \& Technology \\ Jeddah, Saudi Arabia \\ E-mail: sayeed@ubt.edu.sa
}

Received: September 14, 2018 Accepted: October 23, 2018 Published: November 5, 2018 doi:10.5296/ijafr.v8i4.13864

URL: https://doi.org/10.5296/ijafr.v8i4.13864

\begin{abstract}
It has been observed and believed that that employee engagement and organizational culture are directly or indirectly linked with organizational performance. Engagement of employees is well aware of the business context, and works with colleagues to improve the performance within the job for the benefit of the organization. Organizational culture is the core competency for an organization. It will impact effectiveness or performance of the individuals, the groups and the whole organization. The purpose of the present study is to find out the level of faculty engagement and perception about the prevailing organizational
\end{abstract}


culture and its relationship with each other. For this purpose 221 faculty members working in various NCAAA accredited University of Saudi Arabia with more than 2 years of working experience were taken as subject using survey method and purposive random sampling techniques were used to collect the data. It has been found that faculty members were revealing high level of employee engagement and moderate level of organizational culture which leads the University to achieve world class NCAAA accreditation. The results were also discussed on the basis of certain demographic variables like gender, level of education etc. and the results were discussed and suggestions were made accordingly.

Keywords: Trust, Affective engagement, Intellectual engagement, Organizational culture, Openness and risk taking

\section{Introduction}

\subsection{Employee Engagement}

Employee engagement's prominence in organizational concerns is largely down to a shared and somewhat inherent belief that it is linked to productivity. Employee engagement was a popular concept and was extensively discussed in different fields from 1990s until now. In today's complex economy, employee engagement especially becomes crucial for every organization. Because of they strive to attain competitive advantage over the others through use of intellectual capital. Meyer et al (2002) identified that "there are numerous definitions of employee engagement, but they all are agree that employee engagement is desired by organizations, has an organizational purpose. For example, Kahn (1990) presented employee engagement as "the harnessing of organizational members' selves to their work roles; in engagement, employees express themselves physically, cognitively and emotionally during role performances". Moreover, Hewitt Associates LIC (2004) defined employee engagement as "the level of commitment and involvement an employee has towards their organization and its values". It describes that an engaged employee is intellectually and emotionally bound with the organization, enthusiasm with its goals.

Employee engagement is defined by Robinson, Perryman and Hayday (2004) as "a positive attitude held by the employee towards the organization and its value. An engaged employee is aware of the business context, and works with colleagues to improve the performance within the job for the benefit of the organization.

Employee engagement does not have one simple or accepted definition. The Chartered Institute of Personnel and Development take a three dimensional approach to defining employee engagement:

- Intellectual Engagement: Thinking hard about the job and how to do it better. Intellectual engagement is an absorbing, creatively energized focus resulting in a deep personal commitment to exploration, investigation, problem-solving and inquiry over a sustained period of time.

- Affective Engagement: Feeling positively about doing a good job. 


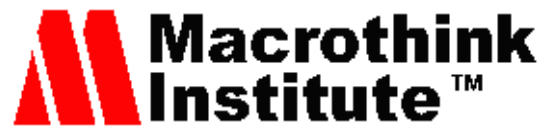

International Journal of Accounting and Financial Reporting

- Social Engagement - actively taking opportunities to discuss work-related improvements with others at work

This definition may be suitable for some organizations, job roles and employees but not all. In some job like manufacturing includes repetitive work, do not necessarily evoke intellectual engagement, nor do some people seek intellectual engagement from their work. It may be that in these circumstances the other dimensions have a substitutionary role in overall engagement. Another, perhaps more encompassing definition comes from David Guest, Professor of Organizational Psychology at Kings College London. He describes employee engagement as "a workplace approach designed to ensure that employees are committed to their organizations goals and values, motivated to contribute to organizational success and able at the same time to enhance their own sense of wellbeing"

Saks (2006) defined engagement as 'a distinct and unique construct consisting of cognitive, emotional and behavioural components that are associated with individual role performance', distinguishing between job engagement and organizational engagement.

Despite the massive interest, activities and strong belief in the importance of employee engagement, there has not been the level of study or definitive evidence that many professionals would expect. It is even argued that what engagement is or does has not been rigorously conceptualized, much less empirically studied (Macey and Schneider, 2008). For many, there is an assumed causal relationship between employee engagement and productivity but it is important to look at the factual evidence.

\subsection{Organizational Culture}

Organizational culture has received extraordinary attention ever since the concept was proposed by American scholars in 1980's. By contrast with the management practice in Japanese companies, the concept of organizational culture was proposed and related theories were developed. The academia and managerial practitioners have reached the consensus that organizational culture is the core competency for an organization. It will impact effectiveness or performance of the individuals, the groups and the whole organization. There is no single definition for organizational culture. The topic has been studied from a variety of perspectives ranging from disciplines such as anthropology and sociology, to the applied disciplines of organizational behaviour, management science, and organizational commitment. The following definitions are views of authors from the applied sciences.

Robbins (2003) postulated that culture, as a concept, has had a long_history. In the last decade, it has been used by some organizational researchers and managers to indicate the climate and practices that organizations develop around their handling of people or to refer to the espoused values and credo of an organization. Schein (1999) defined culture as a pattern of shared basic assumptions that the group learned as it solved problems of external adaptation and internal integration that has worked well enough to be considered valid and, therefore, to be taught to new members as the correct way to perceive, think, and feel in relation to those problems. Aswathappa (2003) referred to culture as a complex whole which includes 


\section{Mll Macrothink}

International Journal of Accounting and Financial Reporting

ISSN 2162-3082

2018, Vol. 8, No. 4

knowledge, belief, art, morals, law, custom, and other capabilities and habits acquired by man in a society.

The OCTAPACE culture is characterized by the occurrence of openness, confrontation, trust, authenticity, pro-activity, autonomy, collaboration and experimentation, it deals with the extent to which these values are promoted in the organization (Pareek and Rao, 2003).

Openness \& Risk Taking: Employees feel free to express their ideas and the organization is willing to take risks and do experiment with new ideas and new ways of doing things.

Confrontation: Employees face the problems and work jointly with others concerned to find its solution. They face the issues openly without hiding them or avoiding them for fear of hurting each other.

Trust: The employees, department and groups trust each other and can be relied upon to 'do' whatever they say they will do.

Authenticity: Authenticity is the value underlying trust. It is the willingness of a person to acknowledge the feelings he/she has, and to accept him/her as well as others who relate to him/her as persons.

Pro-action: Employees are action - oriented, willing to take initiative and to show a high degree of pro-activity. They anticipate the issues and act or respond to the needs of the future.

Autonomy: Autonomy is the willingness to use power without fear, and helping others to do the same. Employees have some freedom to act independently within the boundaries imposed by their role/job.

Collaboration: Collaboration involves working together and using one another's strength for a common cause. Individuals, instead of solving their problems by themselves, share their concerns with one another and prepare strategies, work out plans of action, and implement them together.

Experimentation: Experimentation as a value emphasizes the importance given to innovation and trying out new ways of dealing with the problems in the organization.

\section{Literature Review}

Ilyasa et al. (2018) conducted a study on 563 employees to study the influence of the culture of the organization, knowledge sharing and employee engagement to the employee work innovation at health social security organizing body. This result from this research indicated that the organization culture a direct impact positive to the work employees innovation, knowledge sharing a direct impact positive to the work employees innovation, employee engagement a direct impact positive to the work employees innovation, the organization culture a direct impact positive to the employee engagement, Knowledge sharing a direct impact positive to the employee engagement and the organization culture a direct impact positive to the knowledge sharing. As a result, the increase of the work employees' innovation could be achieved if there is a major impact of culture organization, knowledge sharing and employee engagement. 


\section{Mll Macrothink}

International Journal of Accounting and Financial Reporting

ISSN 2162-3082

2018, Vol. 8, No. 4

Brenyah and Darko (2017) examined the relationship between corporate culture and employee engagement among 267 employees in public sector organizations of Ghana and found that achievement and support cultures significantly cause employees to be engaged in the public sector of Ghana whilst power culture has a significant, but negative relationship with employee engagement. The relationship between role culture and employee engagement is not significant.

Jena and Pradhan (2017) study took an exploratory viewpoint of employee engagement based on the extent literature and offers a conceptual model of employee engagement and argued that employee engagement is a positive attitude held by individuals toward their organization and its culture.

Kalia and Verma (2017) conducted a study on organizational culture and employee engagement among hospitality sector employees and found that Organizational culture is an important factor that promotes employee engagement. Among the different dimensions of organizational culture, autonomy and experimentation were found to be significantly related with all the dimensions of employee engagement. Different dimensions of organizational culture were found to be related more with vigor and dedication as compared to an absorption parameter of employee engagement. Trust has predicted dedication and absorption, whereas collaboration influenced only absorption dimension of employee engagement among the hospitality employees.

Shehri et al. (2017) conducted a study on 39 bankers using structured interview technique to investigate the organizational culture enablers and inhibitors of employee engagement in Saudi Banks. The study revealed that the enabler factors that contribute most to employee engagement enablers were training and development, organizational communication, reward, and recognition. Results also revealed that Islamic culture has an influence on employee engagement in Saudi banks.

Zafar and Kaur (2017) conducted a study on 368 faculty members of public and private Universities and found moderate level of organizational culture were prevailing in the Universities and dominant culture components were includes Openness and Risk taking, Confrontation, Pro-action, Collaboration and Experimentation. They also found no significant differences between male and female faculty members and Ph.D and Non Ph.D faculty members on organizational culture.

Zafar et al. (2017) conducted a study of organizational culture among the employees of organized retail sector using OCTAPACE and found moderate level of organizational culture and they also found that female employees of organized retail sectors were more satisfied with the prevailing organizational culture than their male counterparts.

Sarangi and Nayak (2016) conducted a study on employee engagement and organizational success in manufacturing sector among 200 employees and found that the current level of employee engagement and the work related aspects need to be improved for the purpose of effective employee engagement and they also found through their survey and analysis the employees are having different opinion and confidence. They also found through $6 \mathrm{Cs}$ 
parameters like (i) Clarity (ii) Confidence (iii) Convey (iv) Connect (v) Credibility and (vi) Career, the employees are agreed with these parameters to improve the purpose of effective employee engagement in manufacturing companies.

Kazimoto, P. (2016) studied 120 retail employees of Ghana for employee engagement and organizational performance and found that the degree of retail employee engagement and the level of job satisfaction were very high in retailing enterprises however, it was observed that in retailing organizations, employees were found it difficult to make equilibrium of work experience and house life with their employment. This study also shows that despite the association between employee engagement and job satisfaction, there is no relationship between employee engagement and job assignment, which is an important key factor for organization performance.

The U.S. Department of Labor (2015) identified employee engagement as a challenge, with a negative percentage of $35 \%$ or higher for organizations. Therefore, organizational leaders are rapidly finding ways to engage employees for long-term employment.

Thakur, P (2014) conducted a study on 160 IT professional to find out employee engagement in BPO sectors and concluded that there is positive relationship between employee engagement and job satisfaction in IT sector or employee engagement effect positively on job satisfaction.

Sabri et al. (2011) conducted a research on 347 teachers to determine the effect of organizational culture on job satisfaction level of teachers of public and private sector higher education institutes and universities of Lahore which is second largest city of Pakistan and a hub of higher education. Supportive organizational culture may raise the level of job satisfaction of teachers and satisfied teachers may produce healthy, satisfied and creative minds. Empirical findings showed that organizational culture is categorized into two components i.e. organizational culture related to managers and leaders (OCM) and organizational culture related to employees (OCE).

Kantek and Baykal (2009) conducted a study on organizational culture among 180 nursing faculty members and found that strong perceptions have been established in nursing schools in regard to student-oriented practices, and that groups consisting of senior academic personnel and experienced academicians are considered to be better at perceiving the importance of the organizational culture and they recommended to promote policies to enhance the participation in decision-making processes and regularly monitor the cultural changes in the organization.

\subsection{Dependent and Independent Variables}

The employee engagement of accredited faculty is taken as dependent variable in the regression model. The independent variables used in model are Openness (OPEN), Confrontation (CONF), Trust (TRUST), Authenticity (AUTH), Pro-action (PRO), Autonomy (AUTO), Collaboration (COLL) and Experimentation (EXPE). 


\subsection{Hypotheses}

For examining the impact of organization culture on employee engagement the following null hypotheses have been framed.

$\mathrm{H}_{01}$ : Openness has no significant impact on employee engagement.

$\mathrm{H}_{02}$ : Confrontation has no significant impact on employee engagement.

$\mathrm{H}_{03}$ : Trust has no significant impact on employee engagement.

$\mathrm{H}_{04}$ : Authenticity has no significant impact on employee engagement.

$\mathrm{H}_{05}$ : Proaction has no significant impact on employee engagement.

$\mathrm{H}_{06}$ : Autonomy has no significant impact on employee engagement.

$\mathrm{H}_{07}$ : Collaboration has no significant impact on employee engagement.

$\mathrm{H}_{08}$ : Experimentation has no significant impact on employee engagement.

\section{Research Methodology}

\subsection{Sample}

Faculty Members of various High Performing NCAAA Accredited Universities of KSA with more than two years of experience were used as a subject. The questionnaire was distributed among 250 faculty members using purposive random sampling technique in various Universities of KSA but only 232 filled responses were returned. After scrutiny of the filled questionnaire, 221 of them were found to be complete in all respect and used for the proposed study.

\subsection{Procedure}

Faculty Members working in various accredited universities of KSA were selected as a sample keeping in mind the availability of the data, cost and distance for the data collection. Only faculties with more than two years of experience were taken in to consideration. The data were collected using survey method. Each of the respondents was contacted by the Researcher and the data was collected through questionnaire. They were asked to fill the questionnaire after going through carefully the given instructions on each scale separately. They were also assured of confidentiality of their responses.

\subsection{Statistical Techniques}

- Organizational Culture: Pareek and Rao (2003) developed OCTAPACE profile consisting of 40 items instrument that gives the profile of organizational ethos in 8 values, were used in the study.

- Employee Engagement Scale: Soane et al. (2012) the ISA Engagement Scale was used. The scale is having nine items and identified three kinds of employee engagement. 


\section{1l Macrothink}

International Journal of Accounting and Financial Reporting

ISSN 2162-3082

2018, Vol. 8, No. 4

\subsection{Analysis of the Data}

The collected data were tabulated as per the research design to meet out the objectives of the study and suitable statistical tools like Mean, Median, S.D., Correlation, t-test / Z score and multiple regression analysis etc. were applied using SPSS software.

\subsection{Model Specification}

For analyzing the impact of organization culture on the employee engagement the multiple linear regression models have been applied using SPSS. The regression model is depicted as:

$$
\begin{gathered}
\text { Employee Engagement }=\beta_{0}+\beta_{1}(\mathrm{OPEN})+\beta_{2}(\mathrm{CONF})+\beta_{3}(\mathrm{TRUST})+\beta_{4}(\mathrm{AUTH})+\beta_{5} \\
(\mathrm{PRO})+\beta_{6}(\mathrm{AUTO})+\beta_{7}(\mathrm{COLL})+\beta_{8}(\mathrm{EXPE})+\mathrm{e}_{i t}
\end{gathered}
$$

In the above equation $\beta_{0}$ is constant and $\beta_{i}$ are the regression coefficient of the explanatory variables, while $\mathrm{e}_{i t}$ is the residual error of regression.

\section{Result and Discussions}

Table 1. Mean and SD values of employee engagement and organizational culture among faculty members of accredited universities (N-221)

\begin{tabular}{lll}
\hline COMPONENTS & MEAN VALUE & SD \\
\hline Intellectual Engagement & 3.60 & 1.0 \\
\hline Social Engagement & 3.98 & .81 \\
\hline Affective Engagement & 3.53 & .85 \\
\hline Employee Engagement & 3.70 & .62 \\
\hline Openness and Risk Taking & 3.58 & .59 \\
\hline Confrontation & 3.45 & .95 \\
\hline Trust & 3.66 & .81 \\
\hline Authenticity & 3.54 & .83 \\
\hline Pro-action & 3.31 & .63 \\
\hline Autonomy & 3.47 & .82 \\
\hline Collaboration & 3.38 & .72 \\
\hline Experimentation & 3.47 & .78 \\
\hline Organizational Culture & 3.48 & .34 \\
\hline
\end{tabular}

Source: Authors calculations 


\section{MlMacrothink}

International Journal of Accounting and Financial Reporting ISSN 2162-3082

It is clear from the above Table that Faculty members of NCAAA accredited Universities were showing high level of employee engagement. It revealed that the dominant components were social engagement, means faculty members actively taking opportunities to discuss work-related improvements with others at work, intellectual engagement means faculty members thinking hard about the job and how to do it better, and affective engagement means faculty were feeling positively about doing a good job respectively. This attributes of faculty members positively contributing in enhancing the standard of the accredited university and giving positive image in the society.

Faculty members perceived prevailing organizational culture as moderate which is quite surprising because their level of employee engagement is very high. Trust, Openness \& Risk Taking, Authenticity and Autonomy were found to be dominant organizational culture component. It reveals that the employees, department and groups trust each other and can be relied upon to 'do' whatever they say they will do. Employees feel free to express their ideas and the organization is willing to take risks and do experiment with new ideas and new ways of doing things. Authenticity is the value underlying trust, it is the willingness of a person to acknowledge the feelings he/she has, and to accept him/her as well as others who relate to $\mathrm{him} / \mathrm{her}$ as persons and Autonomy is the willingness to use power without fear, and helping others to do the same. Employees have some freedom to act independently within the boundaries imposed by their role/job.

Table 2. Mean, SD and $\mathrm{Z}$ values of employee engagement and organizational culture among male and female faculty members of accredited universities

\begin{tabular}{llllll}
\hline COMPONENT & $\begin{array}{l}\text { MEAN } \\
\text { (MALE-138) }\end{array}$ & SD & MEAN & SD & $\begin{array}{l}\text { Z } \\
\text { (FEMALE }\end{array}$ \\
\hline Intellectual Engagement & 3.60 & .93 & 3.60 & 1.14 & .037 \\
\hline Social Engagement & 4.01 & .83 & 3.93 & .79 & .578 \\
\hline Affective Engagement & 3.37 & .84 & 3.79 & .84 & $3.681^{* *}$ \\
\hline Employee Engagement & 3.66 & .58 & 3.78 & .70 & 1.405 \\
\hline Openness and Risk Taking & 3.50 & .59 & 3.71 & .61 & $2.606^{*}$ \\
\hline Confrontation & 3.37 & 1.02 & 3.59 & .83 & 1.766 \\
\hline Trust & 3.72 & .81 & 3.55 & .82 & 1.383 \\
\hline Authenticity & 3.51 & .88 & 3.58 & .78 & .552 \\
\hline
\end{tabular}




\begin{tabular}{llllll}
\hline Pro-action & 3.31 & .70 & 3.32 & .52 & .209 \\
\hline Autonomy & 3.36 & .84 & 3.65 & .78 & $2.504^{*}$ \\
\hline Collaboration & 3.34 & .71 & 3.44 & .77 & .940 \\
\hline Experimentation & 3.45 & .79 & 3.50 & .77 & .214 \\
\hline Organizational Culture & 3.46 & .37 & 3.54 & .29 & $2.020^{*}$ \\
\hline
\end{tabular}

* Significant at .05 level and **Significant at .01 level

It is clear from the above Table that both the male and female faculty members were having high level of employee engagement and no significant difference of mean were observed between the two variable. But significant difference of means were observed on the dimension of affective engagement and female faculty members were showing high level of affective engagement than male faculty members which is significant at .01 level of significance, means female faculty members feeling more positive about doing a good job than their male counterparts.

It is also evident from the Table that significant differences of means were observed on overall organizational culture which is significant at .05 level of significance. And also on the dimensions of Openness, Risk Taking and Autonomy in all the cases female faculty members were perceiving high Openness and Risk taking means female faculty members feel more free to express their ideas and the organization is willing to take risks and do experiment with new ideas and new ways of doing things than their male counterpart. On the dimensions of Autonomy also female faculty members shown willingness to use power without fear, and helping others to do the same and have some freedom to act independently within the boundaries imposed by their role/job than male faculty members of accredited universities. The overall organizational culture was perceived by female faculty members better than male faculty members and the difference were found to be significant at .05 level of significance.

Table 3. Mean, SD and $\mathrm{Z}$ values of employee engagement and organizational culture among $\mathrm{Ph}$. D and Non Ph.D. faculty members of accredited universities

\begin{tabular}{llllll}
\hline COMPONENT & $\begin{array}{l}\text { MEAN } \\
\text { (Ph.D.- 99) }\end{array}$ & SD & $\begin{array}{l}\text { MEAN } \\
\text { (NON Ph.D. }-\end{array}$ & SD & $\begin{array}{l}\text { Z } \\
\text { VALUE }\end{array}$ \\
\hline Intellectual Engagement & 3.57 & 1.03 & 3.63 & 1.0 & .362 \\
\hline Social Engagement & 3.95 & .84 & 4.0 & .79 & .437 \\
\hline
\end{tabular}




\section{Macrothink}

International Journal of Accounting and Financial Reporting

ISSN 2162-3082

2018, Vol. 8, No. 4

\begin{tabular}{llllll} 
Affective Engagement & 3.52 & .86 & 3.55 & .85 & .365 \\
\hline Employee Engagement & 3.68 & .62 & 3.73 & .63 & .481 \\
\hline Openness and Risk Taking & 3.46 & .57 & 3.66 & .61 & $2.324^{*}$ \\
\hline Confrontation & 3.45 & .97 & 3.47 & .94 & .010 \\
\hline Trust & 3.67 & .77 & 3.64 & .85 & .208 \\
\hline Authenticity & 3.48 & .84 & 3.59 & .84 & .877 \\
\hline Pro-action & 3.31 & .60 & 3.32 & .66 & .159 \\
\hline Autonomy & 3.43 & .82 & 3.50 & .83 & .732 \\
\hline Collaboration & 3.32 & .72 & 3.43 & .73 & 1.144 \\
\hline Experimentation & 3.37 & .77 & 3.56 & .79 & 1.732 \\
\hline Organizational Culture & 3.44 & .35 & 3.52 & .34 & 1.765 \\
\hline
\end{tabular}

It is clear from the Table that no significance of difference between means were observed on employee engagement and it's all components by Ph.D and Non Ph.D. degree holders faculty members. It reveals that both the kind of faculty members were shown same level of employee engagement and education has no role as far as employee engagements are concerned.

Similarly, no significance of difference between the means has been observed on the dimensions of organizational culture and over all organizational culture but significant difference of means has been observed on the dimensions of openness and risk taking which were found to be significant at .01 level of significance and surprising non Ph.D. degree holders faculty members were having high level of openness and risk taking. Means they feel free to express their ideas and the organization is willing to take risks and do experiment with new ideas and new ways of doing things they are looking for than Ph.D. degree holders faculty members. 
Table 4. Correlation between employee engagement and organizational culture among faculty members of accredited universities (N-221)

\begin{tabular}{lllll}
\hline COMPONENTS & $\begin{array}{l}\text { Intellectual } \\
\text { Engagement }\end{array}$ & $\begin{array}{l}\text { Social } \\
\text { Engagement }\end{array}$ & $\begin{array}{l}\text { Affective } \\
\text { Engagement }\end{array}$ & $\begin{array}{l}\text { Employee } \\
\text { Engagement }\end{array}$ \\
\hline Openness and Risk Taking & .087 & $.160^{*}$ & .068 & $-.147^{*}$ \\
\hline Confrontation & .121 & .050 & $.139^{*}$ & $.150^{*}$ \\
\hline Trust & $.172^{*}$ & $.159^{*}$ & .098 & $.206^{* *}$ \\
\hline Authenticity & $.251^{* *}$ & .067 & $.269 * *$ & $.228^{* *}$ \\
\hline Pro-action & .097 & .083 & .126 & $.145^{*}$ \\
\hline Autonomy & .105 & $.185^{* *}$ & .047 & .114 \\
\hline Collaboration & $.186^{* *}$ & .058 & .103 & $.171^{*}$ \\
\hline Experimentation & .031 & .001 & .122 & .039 \\
\hline Organizational Culture & $.180^{* *}$ & .012 & $.247^{* *}$ & $.204^{* *}$ \\
\hline
\end{tabular}

It is evident from the Table that openness and risk taking component of organizational culture is positively correlated with social engagement but openness surprisingly negatively correlated with employee engagement. It reveals that faculty members' feels if the culture is very open and organization allows taking risk in making any decision without proper control and guidance from the leadership in that case faculty feels least engaged than the case when there is proper control of leadership. Confrontation has been found to be positively correlated with affective engagement and over all employee engagement, which denotes that if the University will be able to give a culture of confrontation where faculty can discuss any issue and resolve problem without affecting the sentiments of others, they will feel good doing such kind of job their engagement will also go up. Authenticity has been also found to be positively correlated with intellectual and affective engagement as well overall employee engagement, which highlights that if the faculty feels that the culture is trust worthy and feeling, expression and concern shown by colleagues are genuine then he or she will more engaged in the job that is assigned. Proaction also has been found to be positively correlated with overall employee engagement but not correlated with any component of employee engagement like intellectual, social \&affective engagement. Similarly, Autonomy has been found to be positively correlated with social engagement, but not found correlated with any other component of employee engagement proves that openness and autonomy if given beyond a certain point it will not make any impact on employee engagement means faculty 
feels that a culture of autonomy and openness and risk taking should not be free floating rather should be under the able guidance of proper leadership. Further, Collaboration has been found to be positively correlated with intellectual engagement and overall employee engagement. Organizational culture has been found to be positively and significantly correlated with intellectual engagement, affective engagement and overall employee engagement means the accredited University were having organizational culture that leads to high level of intellectual and affective employee engagement which leads to high level of world class performance in the accredited universities.

\section{Findings of Regression Model}

In order to determine the existence of multi-collinearity problem, the simple correlation matrix among independent variables is analyzed. Cooper and Schindler (2003) argued that a multi-collinearity problem exists when correlation scores are 0.8 or greater.

\subsection{Regression Analysis Results}

Table 5. Showing regression analysis

\begin{tabular}{llllllllllll}
\hline $\begin{array}{l}\text { Explanatory } \\
\text { Variables }\end{array}$ & Constant & Open & Conf & Trust & Auth & Pro & Auto & Coll & Expe \\
\hline $\boldsymbol{\beta}_{i}$ & $2.749^{*}$ & $-0.196^{*}$ & $0.098^{*}$ & $0.154^{*}$ & $0.170^{*}$ & $0.089^{*}$ & $-0.163^{*}$ & $0.156^{*}$ & -0.007 \\
& $(0.000)$ & $(0.004)$ & $(0.016)$ & $(0.002)$ & $(0.001)$ & $(0.168)$ & $(0.001)$ & $(0.005)$ & $(0.886)$ \\
\hline $\mathrm{t}-\mathrm{values}$ & 0.965 & 2.641 & -1.994 & 8.259 & -2.047 & 2.826 \\
\hline \multicolumn{7}{c}{$\mathrm{R}^{2}=0.230$} & & Adj. $\mathrm{R}^{2}=0.201$ & & & \\
\hline
\end{tabular}

(*) indicates significant at $5 \%$ level.

Coefficient effect $\left(\boldsymbol{\beta}_{i}\right)$ is a predictor of each variable related to organization culture. The regression analysis results reveal the following observations.

1. The adjusted value of $\mathrm{R}^{2}$ highlights that 0.201 variability in the employee engagement of employees can be explained by organization culture.

2. An F-Test value is 7.92 and p-values less than $5 \%$ for the data variables indicates the very well fit of regression model. In other words, the null hypothesis (Ho: There is no effect of given explanatory variables on dependent variables) is rejected.

3. The regression results highlights that organization culture variables such as Proaction and Experimentation have no significant effect employee engagement at 5\% level of significance.

4. The regression coefficients of the other independent variables of organization culture are statistically significant at 5\% significance level and they have significant influence employee engagement of the employees. 


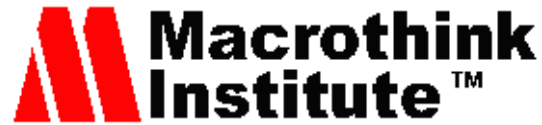

International Journal of Accounting and Financial Reporting

ISSN 2162-3082

2018, Vol. 8, No. 4

As shown in the above table the results of regression analysis can also be depicted in the regression equation form based on regression coefficients.

$$
\begin{gathered}
\mathrm{P}_{i t}=2.749-0.196(\mathrm{OPEN})+0.098(\mathrm{CONF})+0.154(\mathrm{TRUST})+0.170(\mathrm{AUTH})+0.089(\mathrm{PRO}) \\
-0.163(\mathrm{AUTO})+0.156(\mathrm{COLL})-0.007(\mathrm{EXPE})
\end{gathered}
$$

Based on the above equation it can be inferred that Openness (OPEN) and Autonomy (AUTO), have negative but significant influence on employee engagement, whereas Experimentation (EXPE) has negative and insignificant influence on employee engagement.

The $\boldsymbol{\beta}_{1}$ is 0.196 , $\mathrm{t}$-value is 2.951 which is less than p-value at $5 \%$ level of significance. Thus $\mathrm{H}_{01}$ is rejected. It means Openness has significant influence on employee engagement of faculty members.

The $\boldsymbol{\beta}_{2}$ coefficient highlights 0.098 influence of Confrontation (CONF) on employee engagement of employees. The results are statistically significant at $5 \%$ significance level. The $\mathrm{t}$-value is 2.426 which is less than p-value at $5 \%$ level of significance. Thus $\mathrm{H}_{02}$ is rejected and it is inferred that the Confrontation has significant influence on employee engagement.

Trust (TRUST) reveals positive correlation with employee engagement. The $\boldsymbol{\beta}_{3}$ reflects 0.154 influence on the employee engagement. t-value is 3.196 and p-value is less at $5 \%$ significance level. Hence, $\mathrm{H}_{03}$ is rejected and it is inferred that the Trust has significant influence on employee engagement.

The regression results reveal that Authenticity (AUTH) has positive and significant influence on employee engagement. The $\boldsymbol{\beta}_{4}$ coefficient shows 0.170 influences on the employee engagement, t-value is 3.535 and p-value is less at $5 \%$ significance level. Hence $\mathrm{H}_{04}$ is rejected. Means Authenticity in the culture has significant impact on the employee engagement.

The regression coefficient $\boldsymbol{\beta}_{5}$ which measures Proaction (PRO) has 0.089 influences on employee engagement of sample employees. The $t$-value is 1.384 and p-value is more at $5 \%$ significance level. Hence $\mathrm{H}_{05}$ is accepted, which depicts that Proaction has insignificant impact on the employee engagement.

The regression results reveal that Autonomy (AUTO) has negative and significant influence on employee engagement. The $\boldsymbol{\beta}_{6}$ coefficient shows 0.163 influences on the employee engagement, t-value is 3.357 and p-value is less at 5\% significance level. Hence $\mathrm{H}_{06}$ is rejected. Thus it is concluded that Autonomy of Employees has significant impact on the employee engagement.

The regression coefficient $\boldsymbol{\beta}_{7}$ which measures Collaboration (COLL) has 0.156 influences on employee engagement of sample employees. The t-value is 2.844 and p-value is less at 5\% significance level. Hence $\mathrm{H}_{07}$ is rejected, which confirms that Collaboration has significant impact on the employee engagement.

The regression coefficient $\boldsymbol{\beta}_{7}$ which measures Experimentation (EXPE) has 0.007 influences on employee engagement of sample employees. The t-value is 0.143 and p-value is more at $5 \%$ 
significance level, hence $\mathrm{H}_{08}$ is accepted, which highlights that Experimentation has insignificant impact on the employee engagement.

\section{Conclusions and Suggestion}

This research has been carried to find out the level of employee engagement and prevailing organizational culture on eight dimensions of OCTAPACE and also examined the relationship between organizational culture and its various dimensions and employee engagement among faculty members of NCAAA accredited University. Faculty members of the accredited University were found to be highly engaged and the dominant components are social, intellectual and affective engagement respectively. Organizational Culture has been surprisingly found to be moderate and dominant culture components are Trust, Openness and Risk Taking, Authenticity and Autonomy respectively. The correlation analysis between all eight dimensions of Organizational culture and three dimensions of employee engagement has been calculated and few of them were found positively and significantly correlated. But openness and risk taking component of organizational culture has been found to be negatively correlated with employee engagement which is a matter of further investigation and the future researcher must link this with some other variables. It is also clear from the study that employee culture and organizational culture are very powerful components for making an organization effective and performance oriented as these universities are performing at par with international standard. Hence it is recommended that all University must ensure that they have proper rules regulation, procedures, policies and leadership style for catering high level of employee engagement and conducive organizational culture for over all better performance of the Universities.

\section{References}

Aswathappa, K. (2003). Organizational Behaviour. Bangalore: Publishing House.

Brenyah, R. S., \& Darko, T. O. (2017). Organizational Culture and Employee Engagement within the Ghanaian Public Sector. Review of Public Administration and Management, 5(3), $1-7$.

Hewitt Associate LIC. (2004). Research brief: employee engagement higher at double-digit growth companies. Retrieved February 24, 2016, from www.hewitt.com

Ilyasa, M., \& Ramly, M. (2018). The Effect of Organization Culture, Knowledge Sharing and Employee Engagement on Employee Work Innovation. International Journal of Scientific Research and Management (IJSRM), 6(1), 57-63.

Jena, L. K., \& Pradhan, S. (2017). Research and recommendations for employee engagement: Revisiting the employee-organization linkage. Development and Learning in Organizations: An International Journal, 31(5), 17-19.

Kahn, W. A. (1990). Psychological conditions of personal engagement and disengagement at work. Academy of Management Journal, 33, 692-724. 


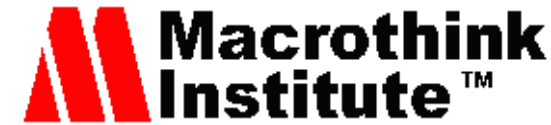

International Journal of Accounting and Financial Reporting ISSN 2162-3082

Kalia, N., \& Verma, Y. S. (2017). Organizational Culture and Employee Engagement: An Interrelationship Study in Hospitality Industry of Himachal Pradesh. International Journal of Human Resource Management and Research (IJHRMR), 7(3), 3-22.

Kantek F., \& Baykal, U. (2009). Organizational culture in nursing schools in Turkey: faculty members' perspectives. International Nursing Review, 56, 306-312.

Kazimoto, P. (2016). Employee Engagement and Organizational Performance of Retails Enterprises. American Journal of Industrial and Business Management, 6, 516-525.

Macey, W., \& Schneider B. (2008). The Meaning of Employee Engagement. Industrial and Organizational Psychology, 1, 3-30.

Meyer, J. P., Stanley, D. J., Herscovitch, L., \& Topolnytsky, L. (2002). Affective, continuance, and normative commitment to the organization: A meta-analysis of antecedents, correlates, and consequences. Journal of Vocational Behavior, 61, 20-52.

Pareek, U., \& Rao, T. V. (2003). Making Organizational Role Effective. Tata McGraw Hill Publishing Company Ltd., New Delhi.

Robbins, S. P. (2003). Organizational Behaviour. New Jersey: Prentice Hall.

Robinson, D., Perryman, S., \& Hayday, S. (2004). The Drivers of Employee Engagement. Brighton: Institute for Employment Studies, IES Report 408.

Sabri, P. S., Illiyas, M., \& Amjad, Z. (2011). Organizational Culture and Its Impact on the Job Satisfaction of the University Teachers of Lahore. International Journal of Business and Social Science, 2(24).

Sarangi, P., \& Nayak, B. (2016). Employee Engagement and Its Impact on Organizational Success - A Study in Manufacturing Company, India. Journal of Business and Management, 18(4), 52-57.

Schein, H. E. (1999). Empowerment, coercive persuasion and organizational learning: do they connect?. The Learning Organization, 6(4), 163-172.

Shehri, M., Laughlin, P. M., Ashaab, A., \& Hamad, R. (2017). The Impact of Organizational Culture on Employee Engagement in Saudi Banks. Journal of Human Resources Management Research, 1-23.

Soane, E., Truss, C., Alfes, K., Shantz, A., Rees, C., \& Gatenby, M. (2012). Development and Application of a New Measure of Employee Engagement: The ISA Engagement Scale. Human Resource Development International.

Thakur, P. (2014). A Research Paper on the Effect of Employee Engagement on Job Satisfaction in IT Sector. Journal of Business Management \& Social Sciences Research, 3(5), 31-39.

U.S. Department of Labor. (2015). Employee Engagement Strategy Final Report. Retrieved from http://www.dol.gov/odep/pdf/20150201EES FinalReport.pdf 


\section{Macrothink}

International Journal of Accounting and Financial Reporting ISSN 2162-3082 2018, Vol. 8, No. 4

Zafar, S., \& Kaur, T. (2017). Impact of Organizational Culture on Job Satisfaction among the University Faculty Members - An Empirical Study. International Journal of Business and Social Science, 8(3), 171-178.

Zafar, S., Miralam, M. S., \& Bhalla, P. (2017). Organizational culture and job satisfaction in organized retail sector. Journal of Business and Retail Management Research, 12(1), 215-224.

\section{Copyright Disclaimer}

Copyright for this article is retained by the author(s), with first publication rights granted to the journal.

This is an open-access article distributed under the terms and conditions of the Creative Commons Attribution license (http://creativecommons.org/licenses/by/4.0/) 